\title{
건설공사장 이동식 방음시설물의 음향특성 \\ Site Mitigation Plan for Noise Sources from Construction Sites by Developing Movable Noise Barriers
}

\author{
이 성 찬†.정 진 연*.임 정 빈* \\ Sung Chan Lee, Jin Yun Chung and Jung Bin Im \\ (Received December 17, 2014 ; Revised January 12, 2015 ; Accepted January 12, 2015)
}

Key Words : Construction Noise(공사장소음), Mitigation Plan(소음저감), Movable Noise Barrier(이동식 방음시설물)

\begin{abstract}
There are a lot of different types of noise from construction site and it depends on construction stage, equipment type and number of operating equipments. The problem is that the almost noise from construction site is high level and some kinds of noise levels are over $100 \mathrm{~dB}$. In addition, if construction site is located in downtown, there are a few options to reduce noise level. Therefore several site mitigation plans were developed to reduce different types of construction noises such as breaker work, gang form and asphalt saw. They were applied in site and evaluated noise reduction performance. The test result of site insertion loss was between $4 \sim 8 \mathrm{~dB}$ depends on the equipment and type of work.
\end{abstract}

\section{1. 서 론}

도심지에 위치해 있는 건설공사장의 경우 인접건 물과의 거리가 가까운 것이 특징이다. 따라서 주변 에 거주하거나 각종 공사의 진행을 위하여 공사장에 투입되는 건설장비들은 건설공사장내 소음진동발생 의 주된 원인이 되고 있다. 그러나 건설현장에 투입 되는 건설장비의 소음의 측정자체가 쉽지 않고 ${ }^{(1,2)}$ 항타기와 같은 소음레벨이 $100 \mathrm{~dB}$ 가 넘는 건설장비 들이 건설현장에 투입되면 현장에서의 소음저감 대 책은 유명무실해지는 것이 특징이다.

최근 저소음 장비개발에 대한 연구가 진행되고 있으나 건설장비 자체의 소음을 줄이는 일은 쉽지 않고 비용이 많이 발생하기 때문에 건설장비 제조사

$\dagger$ Corresponding Author; Member, Daewoo Institute of Construction Technology

E-mail : sungchan.lee@daewooenc.com

Tel : +82-31-250-1222, Fax : +82-31-250-1263

* Member, Daewoo Institute of Construction Technology
들의 자발적인 저감노력을 기대하기 어렵다. 게다가 저소음장비를 반드시 사용해야 하는 규제기준이 없 어 개발을 한다고 해도 공기가 촉박한 건설공사장에 서는 장비선택 시 소음적인 측면보다는 공사진행에 좀 더 효율적인 장비 선택할 수밖에 없는 실정이다. 따라서 도심지 공사 수행 시 소음으로 인한 민원이 많이 발생하고 있으며 건설장비의 작업 소음저감을 위하여 이동식 방음시설물들을 제작하여 소음원 주 변에 설치하고 있으나 자중 때문에 이동시키기가 용 이하지 않으며 공사진행을 방해하는 경우가 많다. 게다가 건설공사장 소음에 관한 다양한 연구가 진행 되고 있으나 ${ }^{(3-5)}$ 건설현장에서 적용하는 이동식 방음 시설물에 대한 연구는 없는 실정이다.

따라서 이 연구에서는 건설공사장의 이동식 방음 시설물 제작 시 적용 가능한 자재들의 기본적인 흡

\# A part of this paper was presented at the KSNVE 2014 Annual Autumn Conference

* Recommended by Editor Myung Jun Kim

(c) The Korean Society for Noise and Vibration Engineering 
차음성능을 평가하고 건설장비별로 현장에서 적용 가능한 이동식 방음시설물을 개발하고 소음저감성능 을 평가하였다.

\section{2. 건설공사장 이동식 방음시설물}

이 연구에서는 대부분의 이동식 방음시설물에 활 용되는 금속재 가설방음판(Type A)과 2종류의 흡차 음 복합시트(Type B, Type C)를 사용하였다. Type $\mathrm{A}$ 는 현장에서 주로 사용하고 있으나 이동식 방음시 설물을 제작하였을 때 자중 때문에 현장에 이동시키 기가 어려워 공사 작업 효율이 많이 떨어지는 단점 이 있다. Type B와 Type C는 흡차음 복합시트를 사용함으로써 흡차음 재료의 무게를 $40 \sim 50 \%$ 정도 경량화 하였다. 특히 전면에는 흡음재, 후면에는 차 음시트(또는 차음시트와 흡음재)로 복합시트를 구성

Table 1 Material details for mitigation plans

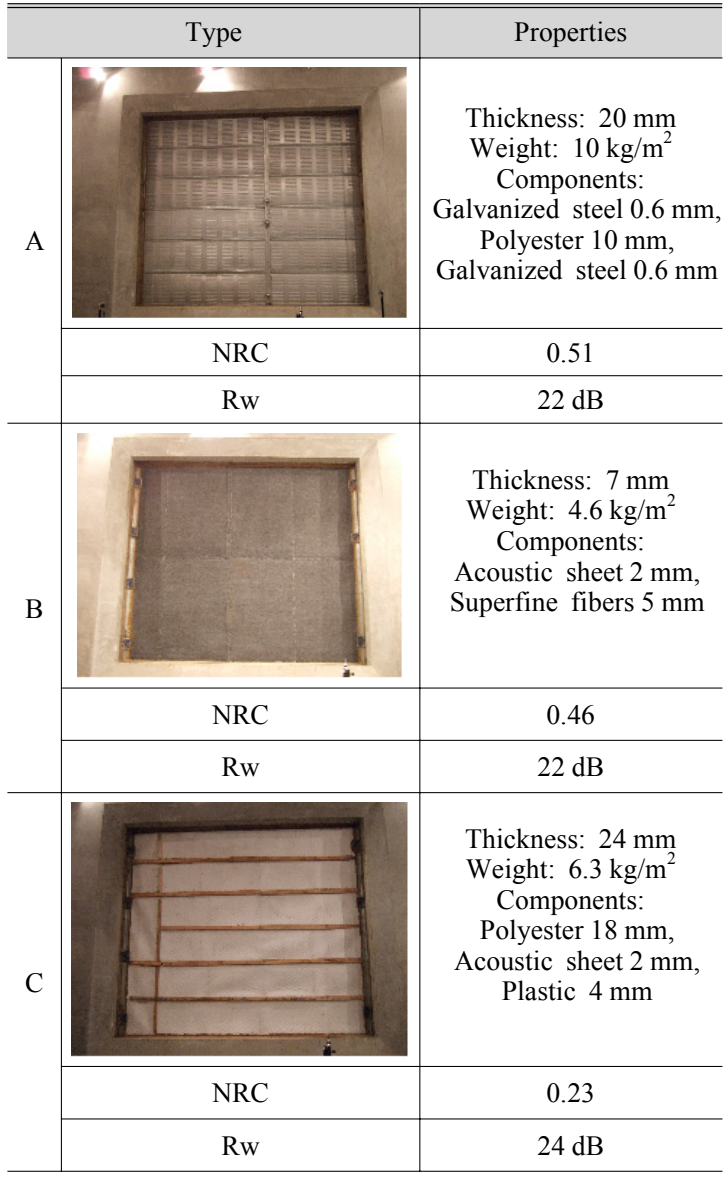

하여 흡음면이 소음원 방향으로 전면 노출시킴으로 써 흡음효과를 최대화하고 반사음을 줄일 수 있도록 제작하였다. 이동식 방음시설물에 적용될 재료의 기 본적인 흡차음 성능을 알아보기 위하여 잔향실에서 실험을 실시하였으며 Table 1에서는 각 타입별 자세 한 구성 및 실험사진, 그리고 흡차음성능평가 결과 의 단일수치 평가량이 제시되어 있다.

흡음성능의 경우 Type $\mathrm{A}$ 의 경우 $\mathrm{NRC}$ 값이 0.51 로 복합시트로 구성된 다른 2종류보다 높았으며 차 음성능의 경우 $\mathrm{Rw}$ 값이 22 24 dB로 비슷한 수준이 었다. 주파수 대역별 측정결과는 Fig. 1 과 같다.

건설현장에는 많은 장비들이 투입되어 공사를 수 행하기 때문에 각 장비별 특성에 맞는 소음저감대책 이 필요하다. 또한 같은 장비라고 해도 작업의 종류 에 따라 발생되는 소음의 특성이 달라지므로 장비의 종류, 작업종류에 따라서 이동식 방음시설물의 형태

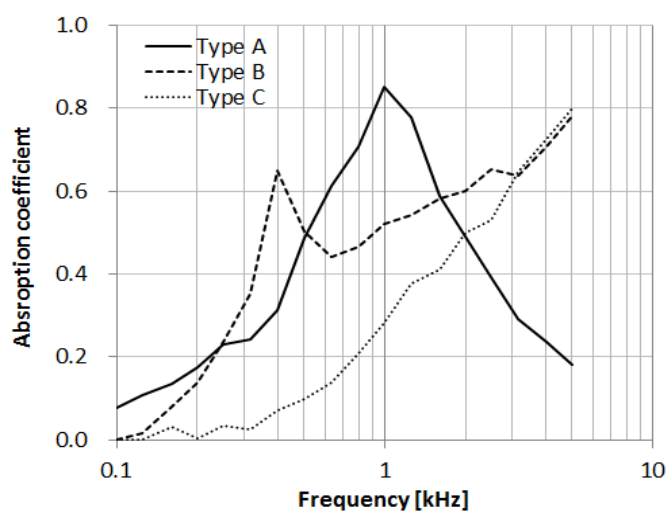

(a) Absorption coefficients

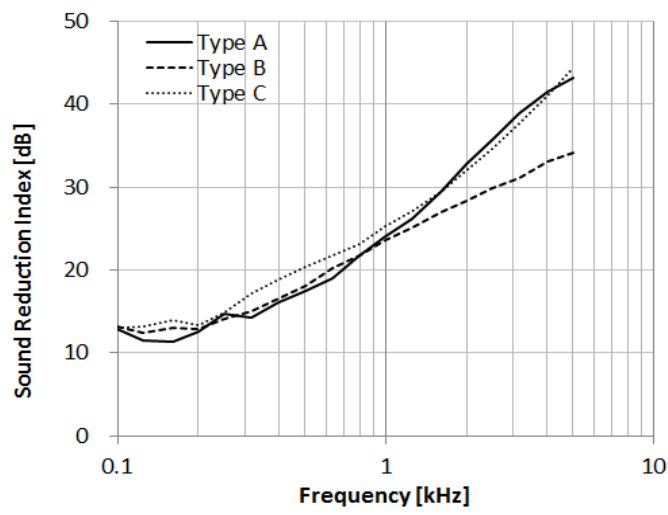

(b) Sound insulation

Fig. 1 Laboratory test results 
및 적용방법이 달라져야 한다. 따라서 이 논문에서 는 Type A, B, C의 흡차음성능 평가결과를 토대로 건설현장에 투입되는 장비중에서 성가심을 가장 많 이 유발하는 장비인 브레이커의 작업 ${ }^{(6)}$ 중 발생하 는 소음 및 엔진작동소음, 거푸집 해체 작업 소음, 아스팔트 컷팅기 소음저감을 위한 이동식 방음시 설물을 제작하여 현장에 적용하고 소음저감효과를 알아보았다.

\section{3. 브레이커 소음저감}

\section{1 브레이커 작업 소음}

3가지 흡차음 구조 (Type A, B, C)로 현장에서 브레이커 작업 시 소음저감을 위한 이동식방음벽을 제작하였다. 브레이커 작업의 특성상 파손되기 쉬운 방음판의 교체를 쉽게 할 수 있는 구조로 제작하였 으며 이를 위해 가설방음판을 $\mathrm{H}$ 빔 사이에 상부에서

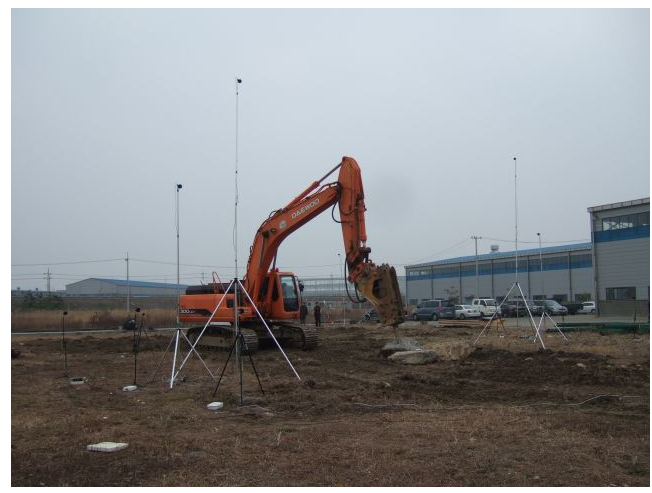

(a) Before installation

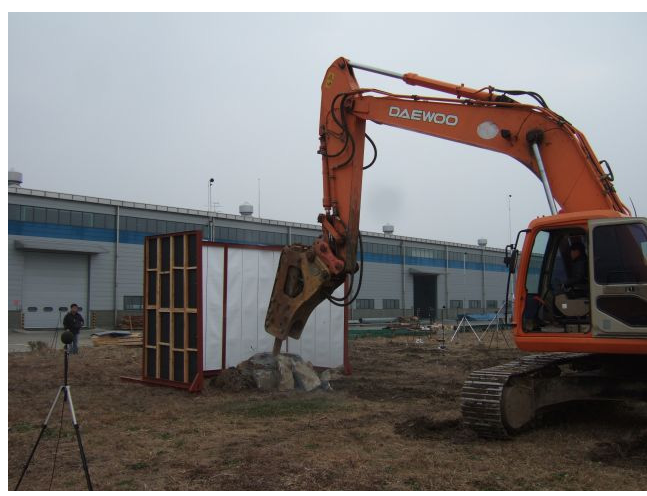

(b) After installation

Fig. 2 Site insertion loss test of temporal barrier for breaker work
삽입하는 방법으로 제작하였다. 브레이커 작업 시 이동식 방음시설물의 설치 전후의 소음레벨을 측정 하였으며 현장 삽입손실 평가모습은 Fig. 2와 같으 며 방음시설물(이동식 방음벽) 시작품에 대한 현장 삽입손실을 측정하기 위해 Fig. 3과 같이 브레이커 를 중심으로 반경 $10 \mathrm{~m}$ 떨어진 위치에 $45^{\circ}$ 간격으 로 마이크로폰을 지면 위 $1.2 \mathrm{~m}$ 높이에 설치하였다. 브레이커로 암을 파쇄할 때 발생하는 소음은 계속 변동하기 때문에 각각의 측정마다 전면 $4 \mathrm{~m}$ 높이에 기준 마이크로폰(Ref. Mic.)을 설치하여 변동소음의 크기에 대한 보정 자료로 이용하였다.

기준 마이크로폰의 측정결과를 이용하여 보정한 측정방향별 삽입손실을 Fig. 4에 표시하였다. 측정

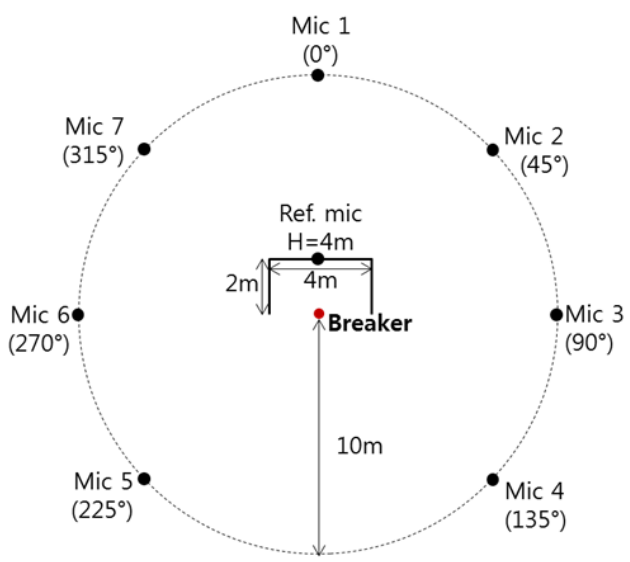

Fig. 3 Measurement position for breaker work

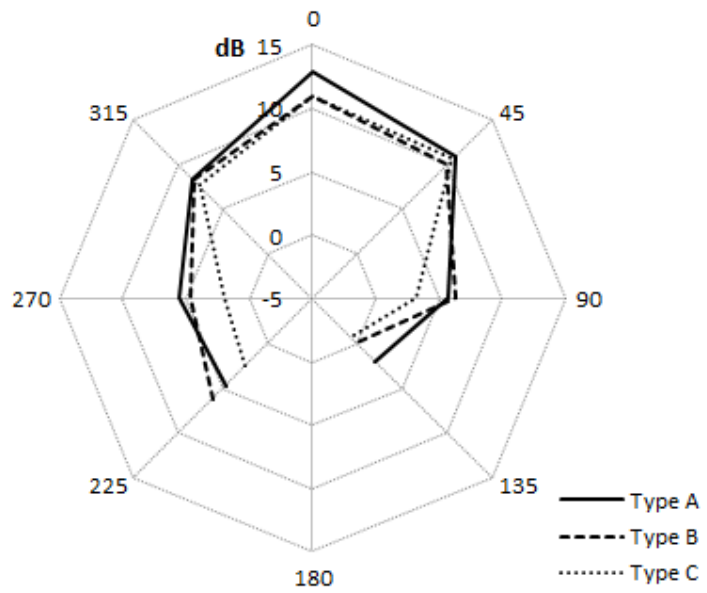

Fig. 4 Insertion loss test result of temporal barrier for breaker work 
결과 금속재 방음판을 사용한 Type A의 삽입손실 이 대체로 전 방향에서 높게 나타났다. 극세사 흡음 재 흡차음 복합시트를 사용한 Type B 및 플라스틱 흡음재 흡차음 복합시트를 사용한 Type $\mathrm{C}$ 의 삽입손

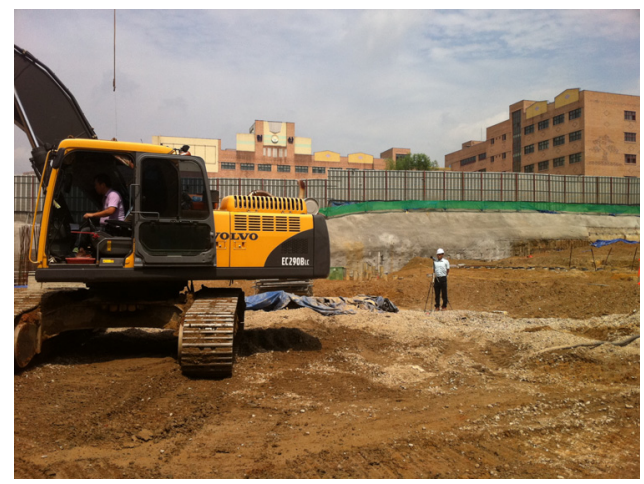

(a) Before installation

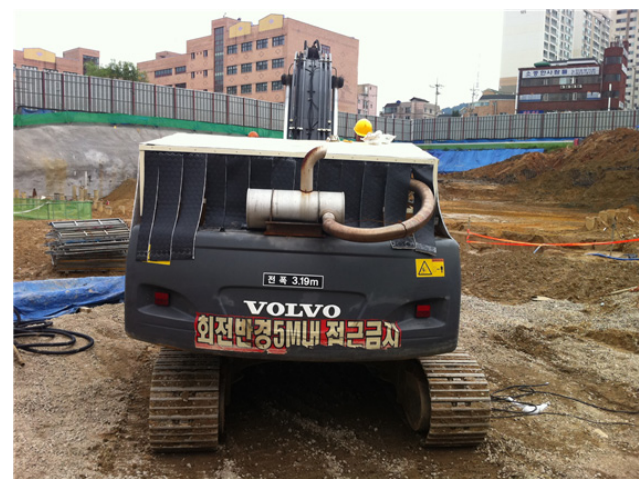

(b) After installation

Fig. 5 Site insertion loss test of temporal barrier for breaker engine noise

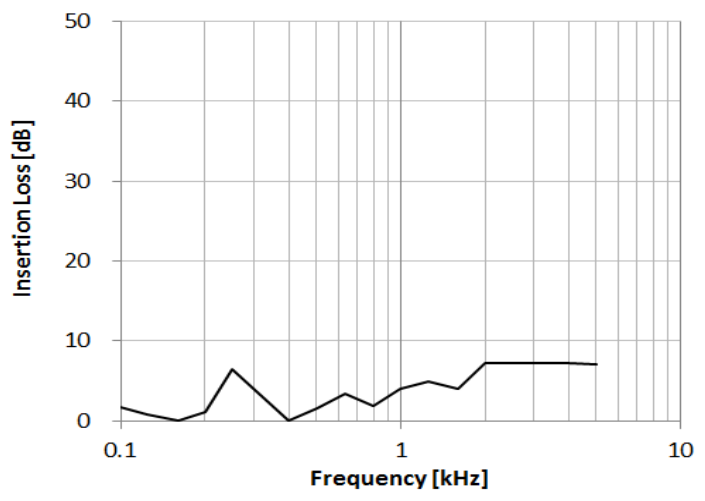

Fig. 6 Insertion loss test result of temporal barrier for breaker engine noise
실은 Type A에 비해 낮으나 비교적 양호한 결과 를 나타내었다. 복합시트를 사용한 이동식 방음벽 의 삽입손실은 $10 \mathrm{~dB}$ 내외이지만 복합시트의 연결 부 틈새를 보완할 경우 삽입손실은 증가할 것으로 예상된다.

\section{2 엔진소음}

브레이커의 엔진 또한 작업 중 소음을 유발시키 는 원인이 되므로 엔진소음을 저감시키기 위한 탈부 착식 방음시설물을 제작하였다. 시작품 제작을 위한 재료는 Type B 흡차음 복합시트를 사용하였고 굴삭 기 작업의 특성상 발생된 열이 배출되도록 측면의 복합시트 소재를 조각으로 만들었다. 방음시설물(이 동식 방음벽) 시작품에 대한 현장 삽입손실을 측정 하기 위해 브레이커를 중심으로 반경 $7.5 \mathrm{~m}$ 떨어진 위치에 마이크로폰을 지면 위 $1.5 \mathrm{~m}$ 높이에 설치하였 다. Fig. 5는 브레이커 엔진가동 시 방음시설물 유무 에 따른 삽입손실을 측정하는 모습이며 Fig. 6은 측정 결과이다. 복합시트를 사용한 이동식 방음벽의 삽입 손실은 약 $4 \mathrm{~dB}$ 로 이는 발생되는 열의 배출을 위해 만들어진 틈새 때문으로, 연결부 틈새를 보완할 경우 삽입손실은 증가할 것으로 예상된다.

\section{4. 거푸집 해체 작업 소음저감}

거푸집 해체 작업 중 발생하는 철재 낙하물의 충 격성 소음으로 인해 공사 현장 주변지역에서 소음민 원이 끊이지 않고 있는 실정이다. 창호 등의 개구부 를 통해 외부로 전파되는 이러한 충격성 소음을 저 감하기 위해서 개구부에 가볍고 탈부착이 용이한 Type B 흡차음 복합소재를 방음커튼 형태로 구성하 여 소음의 전파경로를 차단하고자 하였다. 이를 위 해 공사가 진행 중인 현장에서 방음커튼의 음향삽입 손실을 측정하였다.

\section{1 거푸집 해체 작업 소음}

거푸집 해체 작업을 진행하면서 현장 내부 및 인 접동 내부에서 소음계를 이용하여 1 분 동안의 등가 소음(Leq, $1 \mathrm{~min})$ 을 측정하였다. 측정위치 사이의 거 리는 $28 \mathrm{~m}$ 이며, 방음커튼을 설치하기 전과 방음커 튼을 설치한 경우에 대해 측정을 수행하였다. Fig. 7 은 개구부에 방음커튼을 설치하고 실내에서 거푸집을 


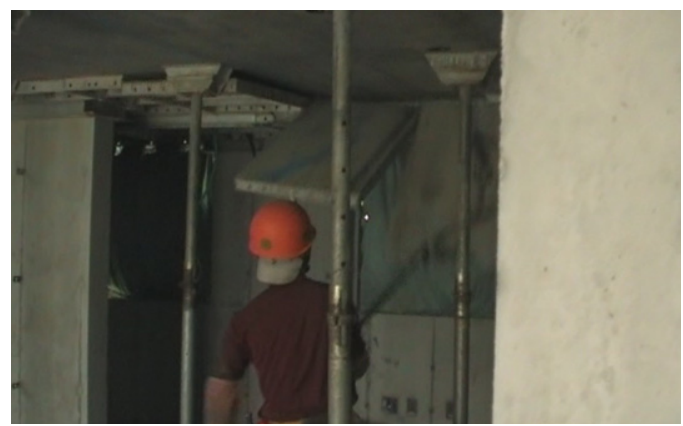

Fig. 7 Demolition work of gang form

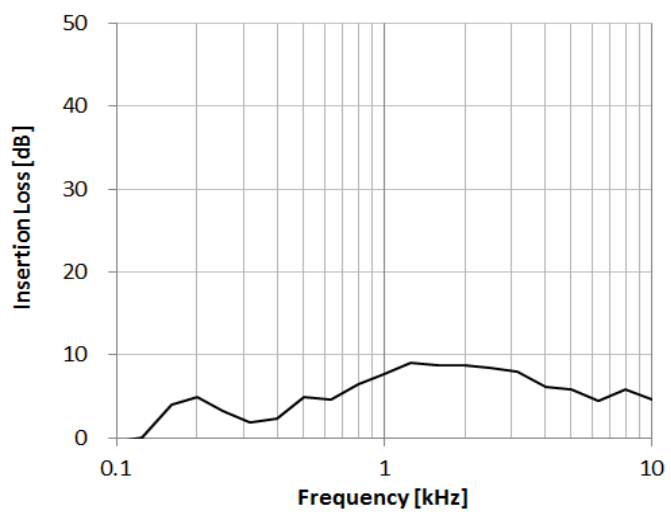

Fig. 8 Insertion loss test result of gang form demolition work

해체하는 전경을 나타낸 것이다.

측정 결과 거푸집 해체 작업 중 발생하는 충격성 소음의 크기는 실내에서 평균 $105 \mathrm{~dB}(\mathrm{~A})$ 내외이며, 최대 $120 \mathrm{~dB}(\mathrm{~A})$ 를 초과하는 경우도 나타났다. 방음 커튼 시공 전·후의 소음저감량 차이는 평균 $8.4 \mathrm{~dB}$ 로 나타났으며 최대 등가소음도로 평가할 경우, 평 균 $10.7 \mathrm{~dB}$ 로 나타났다. 따라서 거푸집 해체 작업 시 방음커튼을 활용할 경우 최대 약 $10 \mathrm{~dB}$ 정도의 소음을 저감할 수 있을 것으로 사료된다.

\section{2 현장 삽입손실 측정}

거푸집 해체 작업 중 발생하는 소음은 단발성의 충격성 소음이므로 방음커튼 설치 유무 및 방음커튼 의 종류에 따른 정확한 성능비교가 곤란하므로 스피 커를 이용한 정상상태(steady state)의 측정을 수행 하였다. 아파트 내부에 설치된 스피커에서 백색잡음 (white noise)을 발생시키면서 내부와 외부에서 소음 계를 이용하여 1 분 동안의 등가소음 $(\mathrm{Leq}, 1 \mathrm{~min})$ 을

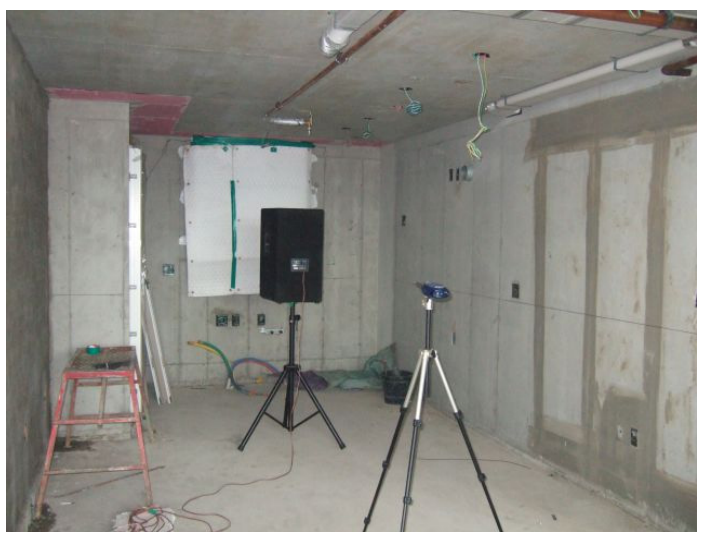

Fig. 9 Site insertion loss test of temporal barrier for gang form demolition work (white noise)

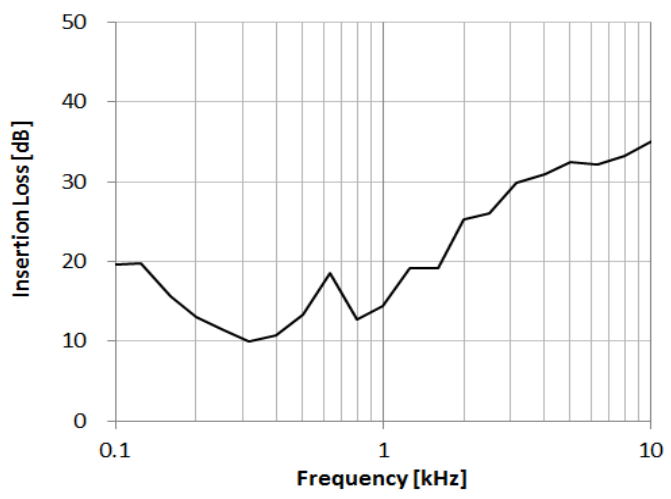

Fig. 10 Insertion loss test result of gang form demolition work with white noise

측정하였다. 이 때 외부에서의 측정위치는 외벽으로 부터 각각 $28 \mathrm{~m}$ 이격되어 있는 3 곳을 정하였다. 측 정 결과 방음커튼 시공 전·후의 소음저감량 차이는 평균 $23.4 \mathrm{~dB}$ 로 나타났다. 거푸집 해체 작업 시에 비해 스피커 실험의 경우, 방음커튼의 소음저감효과 가 매우 높게 나타났으며 특히 $1 \mathrm{kHz}$ 이상의 주파 수 대역에서 효과가 좋은 것으로 나타났다.

\section{5. 아스팔트 컷팅기 소음저감}

Fig. 11(a)와 같은 아스팔트 컷팅기는 건설현장에 서 자주 사용하는 고소음 장비로서 약 $90 \mathrm{~dB}$ 이상 의 소음을 발생함으로써 도심지 이면도로 작업 시 많은 소음민원을 유발하고 있다. 이 연구에서는 아 스팔트 컷팅기와 함께 이동하면서 소음전파를 차단 


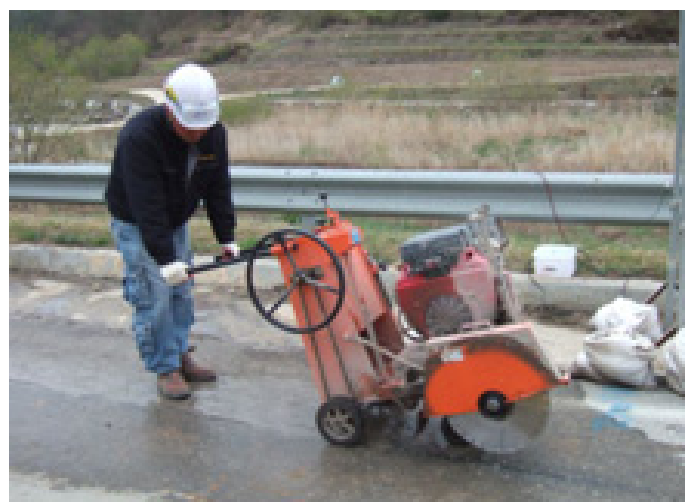

(a) Before installation

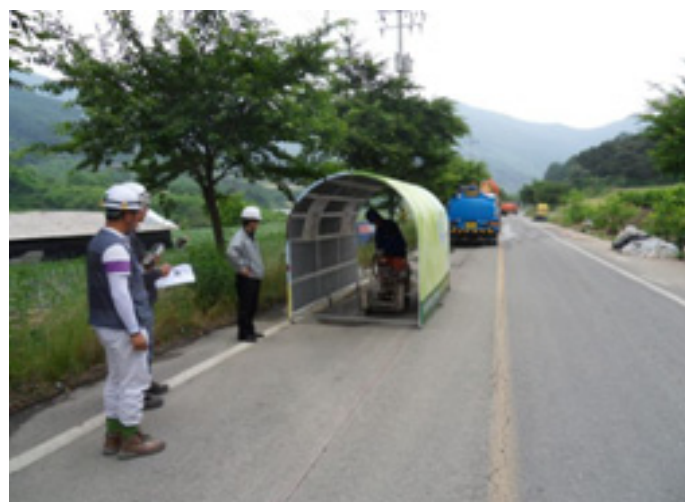

(b) After installation

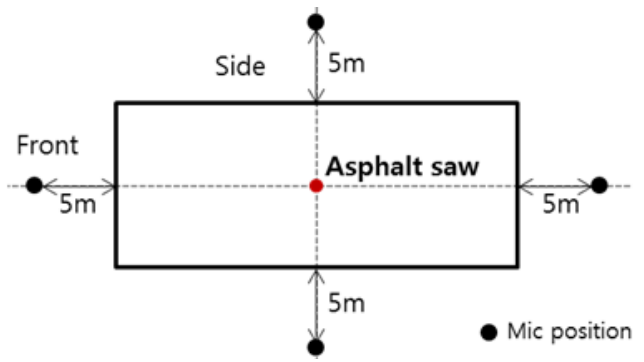

(c) Measurement position

Fig. 11 Site insertion loss test of temporal barrier for asphalt saw

할 수 있도록 Fig. 11(b)와 같이 Type B의 흡차음 복합시트를 이용한 터널형 이동식 방음벽을 개발하 였다. Fig. 12는 터널형 이동식 방음벽 적용 전후의 소음도를 비교한 것으로서 $5 \mathrm{~m}$ 측면과 후면에서 측 정한 결과이다. 측면에서는 $4.4 \mathrm{~dB}$, 후면에서는 5.5 $\mathrm{dB}$ 의 소음저감효과가 있음을 알 수 있다. 이동식 방 음벽의 길이가 제한되어 있고 전면과 후면이 밀폐되 어 있지 않은 점을 고려할 때 $5 \mathrm{~dB}$ 의 소음저감효과는

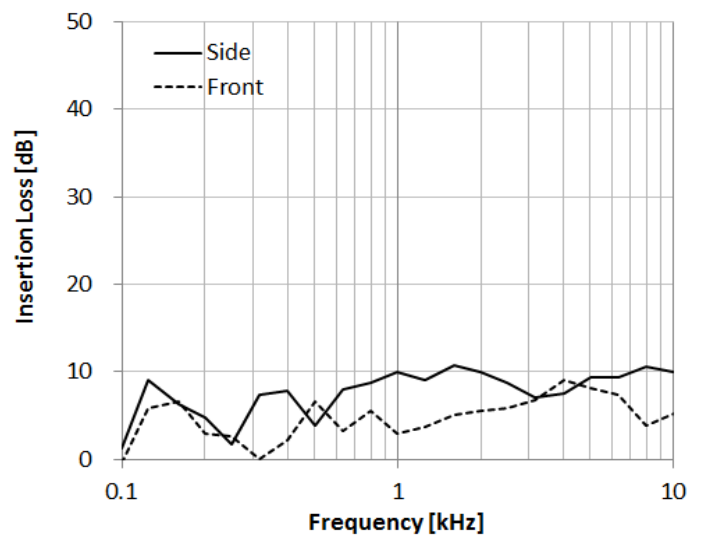

Fig. 12 Insertion loss test result of asphalt saw

양호한 것으로 판단되며, 도심지에서 유용하게 활용 할 수 있을 것으로 사료된다.

\section{6. 결 론}

이 연구에서는 건설공사장에서 민원을 유발하는 소음원인 브레이커 작업 및 엔진소음, 거푸집 해 체 작업 소음, 아스팔트 컷팅기 소음의 소음저감 을 위한 건설현장 이동식 방음시설물을 개발하고 현장에 적용하여 삽입손실을 평가하였다. 브레이 커 작업 소음의 경우 기존의 다형 이동식 방음 시설물의 단점인 자중을 줄이면서도 현장의 삽입 손실 성능은 유지할 수 있는 이동식 방음시설물을 개발하였다. 또한 엔진소음저감을 위한 방음커버 를 제작하였으며 $4 \mathrm{~dB}$ 가량의 소음저감 효과를 관 찰하였다. 거푸집 해체 작업 소음의 경우 방음커 튼으로 제작하여 작업 시 평균 $8.4 \mathrm{~dB}$ 가량 저감 되었다. 아스팔트 컷팅기의 경우 터널형 이동식 방음벽으로 제작하여 $5 \mathrm{~dB}$ 가량의 소음저감효과를 확인하였다. 건설현장에서 공사수행 시 이동식 방 음시설물로 소음을 저감하는 데에는 한계가 있으 므로 향후 건설장비 자체의 소음을 저감하기 위한 연구가 진행되어야 할 것이다.

\section{후 기}

이 연구는 환경부의 “차세대 핵심환경기술개발사 업(과제번호: 2009-11001-0010-0)"의 지원으로 수행 하였습니다. 


\section{References}

(1) Manatakis, E. K., 2000, A New Methodological Trial on Statistical Analysis of Construction Equipment Noise, Applied Acoustics, Vol. 59, No. 1, pp. 67 76.

(2) Yoshinaga, H. et al, 2006, Analysis of Individual Machine Noise in Construction (2), Inter-noise2006.

(3) Chung, J. Y. et al., 2010, Acoustic Properties of Temporary Noise Barriers on Construction Site, Transactions of the Korean Society for Noise and Vibration Engineering, Vol. 20, No. 2, pp. 191 198.

(4) Ballesteros, M. J. et al, 2010, Noise Emission Evolution on Construction Sites. Measurement for Controlling and Assessing Its Impact on the People and on the Environment, Building and Environment, Vol. 45, No. 3, pp. 711 717.

(5) Towers, D. A., 2001, Mitigation of Community Noise Impacts from Nighttime Construction, Construction and Materials Issues 2001, pp. 106 120.

(6) Lee, S. C. and Jeon, J. Y., 2013, Assessment of Annoyance Cause by Different Types of Construction Noises, Transactions of the Korean Society for Noise and Vibration Engineering, Vol. 23, No. 12, pp. 1111 1116.

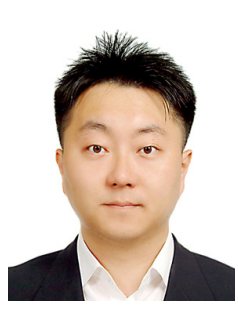

Sung Chan Lee, who is a senior researcher in the architectural engineering research team at Daewoo Institute of Construction Technology has research experience in the area of environmental noise and its assessment, and architectural acoustics.

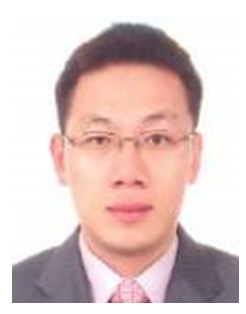

Jin Yun Chung, who is a senior researcher in the architectural engineering research team at Daewoo Institute of Construction Technology has research experience in the area of floor impact noises in the apartments and noise control for plant.

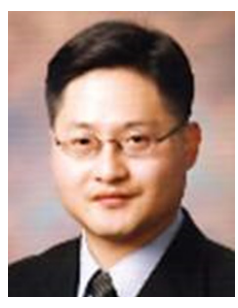

Jung Bin Im, who is a principle researcher in the architectural engineering research team at Daewoo Institute of Construction Technology has research experience in the area of noise and vibration control for plant, and noise monitoring system. 